\title{
A study of epistemological beliefs of EFL learners across gender and educational level
}

Nayebi Limoodehi, Roya

Department of Foreign Languages, Science and Research Branch, Islamic Azad University, Fars, Iran (nlroya@yahoo.com)

Tahriri, Abdorreza $₫$

Faculty of Humanities, University of Guilan, Iran (atahriri@ gmail.com)

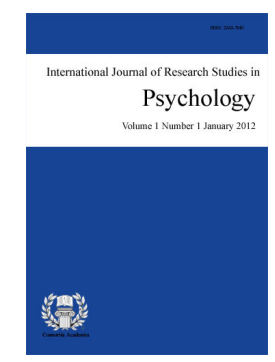

ISSN: $2243-7681$ Online ISSN: $2243-769 \mathrm{X}$

OPEN ACCESS

\section{Abstract}

The present study sought to investigate the impact of EFL learners' educational level and gender on the five dimensions of their epistemological beliefs regarding structure of knowledge, stability of knowledge, source of knowledge, ability to learn and speed of learning. The participants who took part in the study were 101 EFL students studying English literature and English translation in the Islamic Azad University, Rasht Branch, Iran during the spring semester of 2013. They completed the Persian version of Epistemological Questionnaire (Schommer, 1990). The findings showed that there were no statistically significant differences between male and female EFL learners in terms of their epistemological beliefs. In addition, It was found that sophomore student's mean score was significantly higher than that of the freshman students on 'certain knowledge' and 'quick learning' sub-scales indicating that sophomore students had more naive beliefs about 'certain knowledge' and 'quick learning' than freshman students.

Keywords: structure of knowledge; stability of knowledge; source of knowledge; ability to learn; speed of learning; gender; educational level 


\section{A study of epistemological beliefs of EFL learners across gender and educational level}

\section{Introduction}

Epistemological beliefs are defined as individual's beliefs about the nature of knowledge and knowing (Hofer \& Pintrich, 1997). Contemporary psychological research on learners' epistemological conceptions has its roots in the work of Perry (1968 /1999), who interviewed Harvard students' ideas about knowledge during their four year college. In this regard, advancements have been made in the last decade in examinations of epistemological beliefs from different theoretical perspectives (Phan, 2008; Lodewyk, 2007; Cano, 2005; Schommer, 1993), but Schommer's (1990) view has been important in relating to students' academic cognition and performance. She argued that epistemologies might be separable into independent beliefs and proposed five dimensions of epistemological beliefs consisting of structure of knowledge (ranging from the belief that knowledge is isolated bits to the belief that knowledge is interrelated concepts), stability of knowledge (ranging from the belief that knowledge is certain and unchanging to the belief that knowledge is tentative and evolving), source of knowledge (ranging from the belief that knowledge comes from authority to the belief that knowledge comes from reason and empirical evidence), ability to learn (ranging from the belief that ability to learn is gifted at birth to the view that it can be increased) and speed of learning (ranging from the belief that learning takes place quickly or not at all to the belief that learning is gradual) (Schommer, 1990; Schommer, Crouse, \& Rhodes, 1992). To assess these different dimensions of epistemological beliefs, Scommer (1990) developed the first quantitative questionnaire and found evidence to support the multidimensionality of beliefs.

During the last years, studies on epistemological beliefs have increased considerably. One important theoretical assumption in this regard is that learners' epistemological beliefs range from 'naïve' towards 'sophisticated' beliefs (Schommer, 1998). The term 'naïve' is used to indicate a person who thinks that knowledge is certain, absolute, and can be transferred by an authority; on the other hand, people with sophisticated beliefs think that knowledge is more complex, relative, flexible and can be actively constructed by the individual (Brownlee, Purdie, \& Boulton-Lewis, 2001). According to this system, the individual's naïve epistemological beliefs are similar to the behavioristic view while sophisticated epistemological beliefs are similar to the constructivist approach (Howard, McGee, Schwartz, \& Purcell, 2000). There seems to be a relationship between epistemological beliefs and personal characteristics such as problem solving, gender, age, and learning strategies. This study focuses on gender and level in particular.

\subsection{Theoretical Foundations of Epistemological Beliefs (EB)}

Epistemology is a branch of philosophy which is related to the nature and justification of human knowledge (Hofer \& Pintrich, 1997). Educational psychologists are interested in the effects of student's epistemologies on cognition, affect, and student achievement and learning. A review of the various approaches to the study of personal epistemology suggests that there are several ways in which individual thinking about epistemological concerns has been conceptualized. One way has been "developmental models" indicating a systematic progression in the development of one's ideas about knowledge and knowing. A second position is "more-dimensional models" that refer to the personal epistemology as a system of more or less independent beliefs. Each of these clusters of research is reviewed in turn.

\subsubsection{Developmental Models}

The Perry Scheme - Perry (1970) is given credit for beginning the developmental epistemology movement and the study of personal epistemology. He studied 80 male Harvard undergraduates over their four-year college experience, focusing on the students' intellectual development. From open-ended interviews with the students, Perry analyzed how many first-year students believe that simple, unchangeable facts can be transferred by a 
person with authority. When they reach their senior year, students believe that complex, tentative knowledge is resulted from reason and empirical inquiry. According to this study, personal epistemologies is considered as one-dimensional constructs in which individuals pass through these stages based on their cognitive development (Perry, 1970; Kegan, 1982; King \& Kitchener, 2004).

Perry's interviews were classified into four categories. Individuals begin with a dualistic perspective of knowledge, characterized by right and wrong, absolutist view and the belief that truth can be known and the role of the teacher is to communicate it. This is modified as multiplism, when individuals begin to recognize the existence of different viewpoints and the possibility of uncertainty. At the end of this period individuals see conflicting views as equally valid. The movement from multiplism to relativism is characterized by the recognition that some views are better than others. In the positions that follow, individuals develop a growing ability to form commitment within relativism. Although not all students in Perry's study started college as dualists, nor did all complete the trajectory the researcher found, the patterns suggested a structural, systematic progression of thought in their beliefs about knowledge, knowing, and the function of various educational processes.

Women's Ways of Knowing - Following Perry's studies, Belenky, Clinchy, Goldberger, and Tarule (1986) interviewed various women who had different educational backgrounds, ages, and life circumstances. They focused on women's epistemological perspectives based on women's experience. They found women's unique perspectives that they view the world of truth, knowledge, and authority. In addition, they investigated women's conceptions of themselves as knowers. They classified five major epistemological perspectives: Silence, received knowing (similar to Perry's dualism), subjective knowledge (similar to multiplism), procedural knowledge, and constructed knowledge.

Epistemological Reflection Model - Gender perspectives also played a role in the research conducted by Baxter Magolda (1992) in the development of the Epistemological Reflection Model. Similar to Perry's scheme, this model aims the epistemic assumptions that affect interpretation of educational experiences in the college classroom (Baxter Magolda, 2002). Based on the first epistemological study to include longitudinal interviews of equal numbers of males and females, Baxter Magolda suggested a sequence of four ways of knowing: absolute, transitional, independent, and contextual. She concluded that although the overall pattern of development may be similar for men and women, gender-related patterns of knowing may appear in early stages and then converge. Male adopted more "impersonal and individualist" ways of knowing, and women more "personal" and "inter-individualist" ways of knowing.

Reflective Judgment Model - Two other models that followed Perry's work focus on how epistemological assumptions influence thinking and reasoning (King \& Kitchener, 1994; Kuhn, 1991).The primary study in this area is the Reflective Judgment Model (King \& Kitchener, 1994), based on longitudinal study of college students. Although Perry's model has been characterized as concentrating on the nature of knowledge, and "women's ways of knowing" as addressing the source of knowledge (Blenky et al., 1986), this model describes the development of the process of knowing and reasoning.

King and Kitchener built up a seven-stage theory of the reflective judgment model which fit within three clusters: Pre-reflective, quasi-reflective and reflective. In the first cluster, pre-reflective thinking, students believe that knowledge is gained by an authority figure or through first hand observation, rather than through the evaluation of evidence. They suggest that what they know is absolutely correct, and that they know with complete certainty (King \& Kitchener, 2002). In the second cluster, Quasi-reflective thinkers identify that knowledge or knowledge claims consist of elements of uncertainty, which is attributed to missing information or to methods of obtaining the evidence. In line with this, although they use evidence, they do not understand how evidence involves a conclusion, so they tend to view judgments as highly idiosyncratic (King \& Kitchener, 2002). Finally, in reflective thinking, stages six and seven, student shows development in critical thinking as one comes to know. Students who hold these assumptions accept that knowledge claims cannot be made with certainty. In 
fact, based on their evaluation of available data, they make judgments that are most reasonable and about which they are relatively certain. Characteristics of this cluster consist of understanding context, identifying pertinent data, and being active in the construction of knowledge, including reevaluation (King \& Kitchener, 2002).

\subsubsection{Epistemology as a System of Independent Beliefs}

Schommer (1990) started study of epistemology through the lens of independent, multi-dimensional beliefs. In contrast to the work of Perry (1970), Kitchener and King (1981), and Ryan (1984), she suggested that personal epistemology is too complex for it be captured on a one-dimensional dimension. Her study involving university and junior college students used a questionnaire to investigate her hypothesis that "epistemological beliefs are a system of more or less independent beliefs" (p. 499). In proposing that epistemological beliefs are a system of more or less independent dimensions, Schommer claims that learners could be sophisticated in some beliefs but not in others.

After Schommer's (1990) study, researchers suggested to integrate a multi-dimensional model of epistemological beliefs with other cognitive and affective models of learning (Hofer, 2004; Hofer \& Pintrich, 1997; Muis, 2007; Schommer-Aikins, 2004). In line with this, Schommer-Aikins (2004) mentioned, "The need for an embedded systematic model of epistemological beliefs, that is, a model that includes many other aspects of cognition and affect, comes from the assumption that epistemological beliefs do not function in a vacuum" (p. 23). Of particular interesting part of this study are epistemological beliefs models that incorporate metacognitive, affective, and self-regulatory aspects. In another study, Hofer and Pintrich (1997) questioned the innate ability belief dimension. They suggested that innate or fixed ability beliefs are related to the nature of intelligence as a personal, psychological trait of an individual. Therefore, it should be considered as a separate construct from epistemological beliefs. They also pointed out the construct validity issues that have plagued the questionnaire in Schommer's studies. In fact, they questioned whether or not epistemological beliefs can be measured via questionnaires.

After models ranging from Perry's (1970) developmental model to Schommer's (1990) multi-dimensional model, Hofer and Pintrich (1997) recommended the following framework for epistemological beliefs: 1) nature of knowledge, which includes certainty of knowledge and simplicity of knowledge, and 2) process of knowing, which includes source of knowledge and justification for knowing. They defined four subdivisions in this general framework:

$>$ Certainty of knowledge which refers to the degree that one sees knowledge as fixed or fluid.

Dimplicity of knowledge: As Schommer mentioned, knowledge is viewed on a continuum as an accumulation of facts or as highly interrelated concepts.

$>$ Source of knowledge that at the lower levels of the most of the models originates outside the self and external authority, from whom it may be transmitted.

Justification for knowing which refers to how individuals evaluate knowledge claims, consisting of the use of evidence, the use they make of authority and expertise, and the evaluation of experts.

In another study, Hofer and Pintrich (1997) stated that epistemological beliefs may be related to cognition and motivation. They suggested that epistemological beliefs may be related to the goal setting phase of self-regulated learning models (Winne \& Hadwin, 1998; Zimmerman, 2000). Their suggestions prompted epistemology researchers and theorists to develop and investigate integrated models of epistemological beliefs. These new ideas include models relating epistemological beliefs to metacognition, metacognitive monitoring, and self-regulated learning (Hofer, 2004; Muis, 2007; Schommer-Aikins, 2004). Moreover, Hofer (2001) has proposed a general framework of how epistemological beliefs influence learning. According to this framework, learner's epistemological beliefs have effects on their use of strategies and their motivation. Motivation in turn influences strategy use as well. Finally, both motivation and strategy use are related to other learning process. 


\subsection{Objectives of the Study and Research Questions}

This study aimed at investigating the impact of EFL learners' educational level and gender on the dimensions of their epistemological beliefs. The findings from this study may contribute to understanding epistemological beliefs.

The study sought to answer the following questions:

$>$ Are male and female EFL learners' epistemological beliefs different from each other?

$>$ Are freshman and sophomore EFL learners' epistemological beliefs different from each other?

Based on aforementioned research questions, two null hypotheses are put forward:

$H_{01}$ : There are no statistically significant differences between male and female EFL learners in terms of their epistemological beliefs.

$H_{02}$ : There are no statistically significant differences between freshman and sophomore EFL learners in terms of their epistemological beliefs.

\subsection{Significance of the Study}

People are continuously learning during their lives (Sessa, 2006). From both informal and formal education, they continually interpret new information and evaluate it (Merriam \& Caffarella, 2007). Through this learning process, people gradually come to know and internalize knowledge. According to educational psychologists, assumptions or beliefs about knowing and knowledge have an important effect in the learning process. In other words, to understand students' learning process, it is necessary to examine student's epistemological beliefs. Moreover, general epistemological beliefs have been empirically linked to a number of learner outcomes including study strategy use, text comprehension and achievement test performance.

\section{Literature Review}

In recent years, students' beliefs about knowledge and knowing, or epistemological beliefs, have received a good deal of attention from researchers (Hofer \& Pintrich, 1997, 2002; Schommer, 1994). Some researchers began to investigate about younger students' epistemological beliefs in order to test the theory that students develop epistemological beliefs at early ages (Conley, Pintrich, Vekiri, \& Harrisan, 2004; Schommer-Aikins, Duell, \& Hutter, 2005). According to Conley et al. (2004), elementary student's epistemological beliefs about science changed over time. Authors claimed that after nine weeks, students developed more sophisticated beliefs about both the source and certainty of knowledge. They believed that students' epistemological beliefs can be promoted by hands-on or inquiry oriented instruction. It was found that students who were higher achiever in science developed more sophisticated epistemological beliefs. Conley et al. (2004) stated that low achieving children in science in comparison to high achieving children had less sophisticated beliefs. Cano (2005) found that girls had significant differences in simple knowledge, fixed ability, and certain knowledge with respect to school level. In fact, their epistemological beliefs became more realistic as they went through high school.

There have also been a series of research focusing on gender differences in epistemological beliefs, but their results are inconclusive. Some studies have found important gender differences in epistemological beliefs (Cano, 2005; Baxter Magolda, 1992; Belenky et al., 1986). In some studies, females showed more advanced beliefs than males (Lodewyk, 2007; Mason, Boldrin, \& Zurlo, 2006; Schommer \& Dunnel, 1994; Schommer, 1993). According to Schommer (1993), girls were less likely to believe in quick learning and fixed ability than boys. However, Blenky, Clinchy, Goldberger, and Tarule (1986) found that at the early developmental stage of personal epistemology, females consider knowledge as transfer by authority while males view knowledge as 
mastering what is handed down by authority. In this argument, they concluded that at the same stage of the epistemological development, females' epistemological development is less complex than those males who consider the authority.

On the other hand, there are many other studies that find almost no gender differences in epistemological thinking of beliefs (Phan, 2008; Buehl, Alexander, \& Murphy, 2002; Hofer, 2006; Kuhn, Cheney, \& Weinstock, 2000; King \& Kitchener, 1994; Kuhn, 1991). Pintrich (2002) has suggested that there may not be important gender differences in epistemological thinking when it is defined in terms of separate dimensions of epistemological beliefs. That is, when individuals are asked to focus on specific dimensions of epistemological beliefs, rather than more holistic and general ways of thinking, gender differences do not emerge. In line with this, some researchers focused on different aspects of the older students' academic performance. In those researches, it was mainly explored that students who had better comprehension scores used more sophisticated epistemological beliefs in relation to simple and certain knowledge (Kardash \& Scholes, 1996; Schommer, Crouse, \& Rhodes, 1992). Similarly, students who had higher grade point averages used more sophisticated epistemological beliefs in case of quick learning and innate ability (Schommer, 1990; Schommer \& Walker, 1997). Moreover, Schommer (1993) investigated the effect of epistemological beliefs on overall academic performance. Results of analysis showed that the students who less believed in quick learning, simple knowledge, certain knowledge, and fixed ability, were better students in terms of their grade point averages (GPAs).

\section{Methodology}

Participants - The setting of the current study was Islamic Azad University, Rasht Branch. The participants of the study were $101 \mathrm{EFL}$ students studying English literature and English translation during the second half of the spring semester of 2013. Among all the respondents 37 were males and 63 were females. Almost half of the participants were freshmen (51) and half of them were sophomores (50). The mean age was 21.35.

Instrument - Schommer's (1990) Epistemological Questionnaire (EQ) has been frequently used as an effective tool to assess students' beliefs regarding learning and the nature of knowledge. It has 63 items to capture each of the five proposed dimensions of beliefs, for a total of 12 subsets. Items scored are on a 5 point Likert-type scale, with 1 strongly disagree and 5 strongly agree for each item. The items on the questionnaire measured students' epistemological beliefs on five independent dimensions: simple knowledge; certain knowledge; Omniscient authority; innate ability; and quick learning.

Pilot Study - The Epistemological Questionnaire with 63 items in English was translated into Persian by the present researchers. To check for the accuracy of the translation and to ensure that the original concept was preserved, the translated versions were translated back into English by two MA students who had not been previously involved in the questionnaire development and translation process. Then an expert on translation was asked to check the backward translation to ensure that each question, instruction, and response option was accurate. In this way the validity of the translated version was endorsed. Then, the pilot study was done on 30 participants. The purpose of this test was to assess the internal consistency reliability of the items, the feasibility and the time needed to answer the questions, arrange questions, and to see if directions were clear and sufficient. The questionnaire took learners up to 15-20 minutes to complete. As a result of the piloting survey, a small number of changes were made to the questionnaire to assure a higher reliability.

Reliability and Validity Issue - The psychometric validity and reliability of the EQ have been established previously in a number of ways. Its underlying four-factor structure has been replicated with different samples of college students (Bendixen, Dunkle, \& Schraw, 1994; Schommer, 1990; Schommer et al., 1992), adults with high school, college, or graduate school levels of education (Schommer, 1998), and high school students (Schommer, 1993; Schommer \& Dunnel, 1994). The inter-item reliabilities for the set of items constituting each underlying factor range from .63 to .85 and tests have revealed an eight-week test retest reliability of .70 (Schommer, Calvert, Garigliette, \& Bajaj, 1997). Furthermore, in this study, the Cronbach alpha coefficient for 
A study of epistemological beliefs of EFL learners across gender and educational level the entire scale was .87 (Table 1). Thus, the finding indicated that the internal reliability index of the five constructs is acceptable.

\section{Table 1}

Total Reliability Statistics

\begin{tabular}{ccc}
\hline Cronbach's Alpha & $\begin{array}{c}\text { Cronbach's Alpha Based on } \\
\text { Standardize Items }\end{array}$ & Number of items \\
\hline .864 & .869 & 63 \\
\hline
\end{tabular}

\section{Findings}

To answer the first research question which is concerned with differences between male and female EFL learners' epistemological beliefs, descriptive statistics was used. Mean score and standard deviation for dimensions of epistemological beliefs in male and female were calculated (Table 2).

Table 2

Descriptive Statistics for Epistemological Beliefs Sub-Scales

\begin{tabular}{llllll}
\hline & Gender & $n$ & Mean & SD & Std. Error Mean \\
\hline Simple know & male & 37 & 3.3856 & .35610 & .05854 \\
& female & 63 & 3.4467 & .38226 & .04816 \\
Certain know & male & 37 & 3.6192 & .53512 & .08797 \\
& female & 63 & 3.6875 & .51897 & .06538 \\
Authority & male & 37 & 3.4426 & .41830 & .06877 \\
Innate ability & female & 63 & 3.6056 & .47215 & .05948 \\
& male & 37 & 3.5669 & .37022 & .06086 \\
Quick learning & female & 63 & 3.7047 & .39060 & .04921 \\
& male & 37 & 3.4517 & .37119 & .06102 \\
& female & 63 & 3.5143 & .38116 & .04802 \\
\hline
\end{tabular}

The Levene's Test is used to test if $k$ samples have equal variances. Equal variances across samples are called homogeneity of variance. If the resulting P-value of Levene's test is less than the critical value (typically 0.05), the obtained differences in sample variances are unlikely to have occurred based on random sampling from a population with equal variances. Thus, the null hypothesis of equal variances is rejected and it is concluded that there is a difference between the variances in the population. Based on Table $3(p>.05)$, the null hypothesis of equal variances is accepted and it is concluded that there is no difference between the variances in the population, distribution is normal and T-test can be run.

\section{Table 3}

Levene's Test of Equality of Error Variances

\begin{tabular}{llll}
\hline Simple know. & $\begin{array}{l}\text { Equal variances assumed } \\
\text { Equal variances assumed }\end{array}$ & .093 & .761 \\
Certain know. & $\begin{array}{l}\text { Equal variances assumed } \\
\text { Equal variances not assumed } \\
\text { Equal variances assumed }\end{array}$ & .191 & .663 \\
Innate ability & $\begin{array}{l}\text { Equal variances not assumed } \\
\text { Equal variances assumed } \\
\text { Equal variances not assumed }\end{array}$ & .003 & .510 \\
Quick learning & $\begin{array}{l}\text { Equal variances assumed } \\
\text { Equal variances not assumed }\end{array}$ & .007 & .934 \\
\hline
\end{tabular}

T-test is used for comparing the means of two samples (or treatments), even if they have different numbers of replicates. In simple terms, the t-test compares the actual difference between two means in relation to the variation in the data (expressed as the standard deviation of the difference between the means). The first null 
Nayebi Limoodehi, R. \& Tahriri, A.

hypothesis in this study is that there are no statistically significant differences between male and female EFL learners in terms of their epistemological beliefs. Table 4 shows that null hypothesis is accepted $(p>.05)$ and the difference in epistemological beliefs between male and female student is not significant.

Table 4

T-Test for Equality of Means

\begin{tabular}{llllll}
\hline & & $T$ & DF & Sig.(2tailed) & Mean diff. \\
\hline Simple know. & Equal variances assumed & -.791 & 98 & .431 & -.06105 \\
Certain know. & Equal variances not assumed & -.805 & 79.953 & .423 & -.06105 \\
& Equal variances assumed & -.628 & 98 & .531 & -.06831 \\
Authority & Equal variances not assumed & -.623 & 73.699 & .535 & -.06831 \\
& Equal variances assumed & -1.737 & 98 & .086 & -.16300 \\
Innate ability & Equal variances not assumed & -1.793 & 83.035 & .077 & -.16300 \\
& Equal variances assumed & -1.735 & 98 & .086 & -.13775 \\
Quick learning & Equal variances not assumed & -1.760 & 78.880 & .082 & -.13775 \\
& Equal variances assumed & -.801 & 98 & .425 & -.06263 \\
& Equal variances not assumed & -.807 & 77.204 & .422 & -.06263 \\
\hline
\end{tabular}

To answer the second research question which is concerned with differences between freshman and sophomore EFL learners' epistemological beliefs, descriptive statistics was used. Mean score and standard deviation for dimensions were calculated (Table 5).

Table 5

Descriptive Statistics for Epistemological Beliefs Sub-Scales

\begin{tabular}{llllll}
\hline & Year & $N$ & Mean & SD & Std. Error Mean \\
\hline Simple know. & first & 51 & 3.4035 & .36123 & .05058 \\
& second & 50 & 3.4419 & .38268 & .05412 \\
Certain know. & first & 51 & $\mathbf{3 . 5 6 8 0}$ & .57947 & .08114 \\
& second & 50 & $\mathbf{3 . 7 6 6 7}$ & .44046 & .06229 \\
Authority & first & 51 & 3.4656 & .41421 & .05800 \\
& second & 50 & 3.6258 & .48477 & .06856 \\
Ability & first & 51 & 3.6208 & .43577 & .06102 \\
\multirow{4}{*}{ Quick learning } & second & 50 & 3.6912 & .32741 & .04630 \\
& first & 51 & $\mathbf{3 . 3 4 3 1}$ & .34540 & .04837 \\
& second & 50 & $\mathbf{3 . 6 4 4 2}$ & .34455 & .04873 \\
\hline
\end{tabular}

Table 6 illustrates the Levene's test of equality of error variance showing that distribution is normal and T-test can be utilized $(p>.05)$.

Table 6

Levene's Test for Equality of Variances

\begin{tabular}{|c|c|c|c|}
\hline & & $F$ & Sig. \\
\hline Simple know. & $\begin{array}{l}\text { Equal variances assumed } \\
\text { Equal variances not assumed }\end{array}$ & .043 & .836 \\
\hline Certain know. & $\begin{array}{l}\text { Equal variances assumed } \\
\text { Equal variances not assumed }\end{array}$ & 3.984 & .049 \\
\hline Authority & $\begin{array}{l}\text { Equal variances assumed } \\
\text { Equal variances not assumed }\end{array}$ & 1.620 & .206 \\
\hline Ability & $\begin{array}{l}\text { Equal variances assumed } \\
\text { Equal variances not assumed }\end{array}$ & 4.508 & .036 \\
\hline Quick learning & $\begin{array}{l}\text { Equal variances assumed } \\
\text { Equal variances not assumed }\end{array}$ & .054 & .817 \\
\hline
\end{tabular}

The second null hypothesis is that there are no statistically significant differences between freshman and sophomore EFL learners in terms of their epistemological beliefs. Table 7 shows that the null hypothesis is 
A study of epistemological beliefs of EFL learners across gender and educational level

rejected and the significance level in certain knowledge is near .05 which shows a trend and in quick learning, it is significant $(p<.05)$. This difference can be seen in Table 5. It shows that sophomore student's mean score (M $=3.7667)$ is higher than that of the freshman students $(\mathrm{M}=3.5680)$ on certain knowledge subscale indicating that sophomore students had more naive beliefs about certain knowledge than freshman students. Moreover, it shows that sophomore students' mean score $(\mathrm{M}=3.6442)$ is higher than that of the freshman students $(\mathrm{M}=$ 3.3431) on quick learning sub-scale implying that sophomore students had more naive beliefs about quick learning than freshman students.

\section{Table 7}

T-test for Equality of Means

\begin{tabular}{llllll}
\hline & & $t$ & $D F$ & Sig. (2-tailed) & Mean Difference \\
\hline Simple know & Equal variances assumed & -.519 & 99 & .605 & -.03840 \\
& Equal variances not assumed & -.518 & 98.408 & .605 & -.03840 \\
Certain know & Equal variances assumed & -1.937 & 99 & $\mathbf{. 0 5 6}$ & -.19863 \\
& Equal variances not assumed & -1.942 & 93.250 & .055 & -.19863 \\
Authority & Equal variances assumed & -1.787 & 99 & .077 & -.16020 \\
Ability & Equal variances not assumed & -1.784 & 96.033 & .078 & -.16020 \\
\multirow{2}{*}{ Quick learning } & Equal variances assumed & -.917 & 99 & .362 & -.07040 \\
& Equal variances not assumed & -.919 & 92.771 & .360 & -.07040 \\
& Equal variances assumed & -4.385 & 99 & $\mathbf{. 0 0 0}$ & -.30108 \\
& Equal variances not assumed & -4.385 & 98.970 & .000 & -.30108 \\
\hline
\end{tabular}

\section{Discussion}

Table 4 shows that null hypothesis is accepted and the difference in epistemological beliefs between male and female student is not significant $(p>.05)$. This finding is in contrast with some studies that have focused on gender differences in epistemological beliefs (Cano, 2005; Baxter Magolda, 1992; Belenky et al., 1986). Marzooghi, Fouladchang, and Shemshiri (2008) investigated gender difference in undergraduate students' epistemological beliefs in an Iranian university. They used Epistemological Beliefs Questionnaire and found that males had some more naive epistemological beliefs than females. In some studies, females showed more advanced beliefs than males (Lodewyk, 2007; Mason et al., 2006; Schommer \& Dunnel, 1994; Schommer, 1993). According to Schommer (1993), girls were less likely to believe in quick learning and fixed ability than boys. However, Blenky et al. (1986) found that at the early developmental stage of personal epistemology, females consider knowledge as transferred by authority while males view knowledge as mastering what is handed down by authority.

In this argument, they concluded that at the same stage of the epistemological development, females' epistemological development is less complex than those males who consider the authority. On the other hand, there are many other studies that find almost no gender differences in epistemological thinking of beliefs (Phan, 2008; Buehl et al., 2002; Hofer, 2006; Kuhn et al., 2000; King \& Kitchener, 1994; Kuhn, 1991). Pintrich (2002) suggested that there may not be important gender differences in epistemological thinking when it is defined in terms of separate dimensions of epistemological beliefs. That is, when individuals are asked to focus on specific dimensions of epistemological beliefs, rather than more holistic and general ways of thinking, gender differences do not emerge.

Table 5, shows that sophomore students' mean score in certain knowledge and quick learning is significantly higher than that of the freshman students indicating that sophomore students had more naive beliefs about certain knowledge and quick learning than freshman students. This finding is in contrast with what Mason et al. (2006) noted at different ages: more educated students hold more sophisticated beliefs about the nature and acquisition of knowledge. Some researchers found evidence in supporting the effect of grade level on epistemological beliefs of students in middle school or university years (Mason et al., 2006; Cano, 2005; Kuhn et al., 2000; King \& Kitchener, 1994; Schommer, 1993; Jehng, Johnson, \& Anderson, 1993; Perry, 1970). 
Most recently, researchers began to investigate about younger students' epistemological beliefs in order to test the theory that students develop epistemological beliefs at early ages (Conley et al., 2004; Schommer-Aikins, Duell, \& Hutter, 2005). According to Conley et al. (2004), elementary student's epistemological beliefs about science changed over time. Authors claimed that after nine weeks, students developed more sophisticated beliefs about both the source and certainty of knowledge. It was found that students who were higher achiever in science developed more sophisticated epistemological beliefs. Conley et al. (2004) stated that low achieving children in science in comparison to high achieving children had less sophisticated beliefs.

\section{Conclusions}

The first question of the study was concerned with the difference between male and female EFL learners' epistemological beliefs. The findings showed that null hypothesis was accepted $(p>.05)$ and the difference in epistemological beliefs between male and female students was not statistically significant. The second question of the study concerned the difference between freshman and sophomore EFL learners' epistemological beliefs. The findings showed that the significance level in certain knowledge is near .05 which shows a trend. In fact, sophomore student's mean score $(M=3.7667)$ is higher than that of freshman students $(M=3.5680)$ on certain knowledge sub-scale indicating that sophomore students had more naive beliefs about certain knowledge than freshman students. Moreover, in quick learning, difference between freshman and sophomore in epistemological beliefs was significant $(p<.05)$. It shows that sophomore students' mean score $(\mathrm{M}=3.6442)$ was higher than that of freshman students $(M=3.3431)$ on quick learning sub-scale implying that sophomore students had more naive beliefs about quick learning than freshman students.

\subsection{Pedagogical Implications}

The result of this study might help to language teachers to be familiar with college students' beliefs about knowledge, or epistemologies and how they can be supported by teachers. In fact, epistemological beliefs of students and teachers play a significant role in the successful implementation of standards-based curriculum in higher education. In addition, learning and academic performance are influenced by numerous cognitive variables among which epistemological beliefs are the most important ones.

\subsection{Suggestions for Further Research}

This study looks forward. It does not just answer some research questions, but it suggests questions to be pursued in future. It hopefully invites researchers to conduct studies with more participants from different universities in order to make better comparisons and arrive at more generalizability. Also, it is suggested that researchers compare different levels of students such as freshman, sophomore, junior, and senior.

\section{References:}

Baxter Magolda, M. B. (1992). Knowing and reasoning in college: Gender-related patterns in students' intellectual development. San Francisco: Jossey-Bass.

Baxter Magolda, M. B. (2002). Epistemological reflection: The evolution of epistemological assumptions from age 18 to 30. In B. K. Hofer \& P. R. Pintrich (Eds.), Personal epistemology: The psychology of beliefs about knowledge and knowing (pp. 89- 102). Mahwah: Lawrence Erlbaum Associates.

Belenky, M., Clinchy, B., Goldberger, N., \& Tarule, J. (1986). Women's ways of knowing: The development of self, voice and mind. New York: Basic Books.

Bendixen, L. D., Dunkle, M. E., \& Schraw, G. (1994). Epistemological beliefs and reflective judgment. Psychological Reports, 75(3), 1595-1600. http://dx.doi.org/10.2466/pr0.1994.75.3f.1595

Brownlee, J., Purdie, N., \& Boulton Lewis, G. (2001). Changing epistemological beliefs in pre-service teacher education students. Teaching in Higher Education, 6(2), 247-268. http://dx.doi.org/10.1080/13562510120045221 
A study of epistemological beliefs of EFL learners across gender and educational level

Buehl, M. M., Alexander, P. A. \& Murphy, P. K. (2002). Beliefs about schooled knowledge: Domain general or domain specific. Contemporary Educational Psychology, 27, 415-449. http://dx.doi.org/10.1006/ceps.2001.1103

Cano, F. (2005). Epistemological beliefs and approaches to learning: Their changes through secondary school and their influence on academic performance. British Journal Education, 75, 203-221.

Conley, A. M., Pintrich, P. R., Vekiri, I., \& Harrison, D. (2004). Changes in epistemological beliefs in elementary science students. Contemporary Educational Psychology, 29, 186-204. http://dx.doi.org/10.1016/j.cedpsych.2004.01.004

Howard, B. C., McGee, S., Schwartz, N., \& Purcell, S. (2000). The experience of constructivism: Transforming teacher epistemology. Journal of Research on Computing in Education, 32(4), 455-465.

Hofer, B. K. (2004). Epistemological understanding as a metacognitive process: Thinking aloud during online searching. Educational Psychologist, 39(1), 43- 55. http://dx.doi.org/10.1207/s15326985ep3901_5

Hofer, B.K. (2006). Domain specificity of personal epistemology: Resolved questions, persistent issues, new models psychology department. International Journal of Education Research, 45, 85-95. http://dx.doi.org/10.1016/j.ijer.2006.08.006

Hofer, B. K., \& Pintrich, P. R. (1997). The development of epistemological theories: Beliefs about knowledge and knowing and their relation to learning. Review of Educational Research, 67, 88-140. http://dx.doi.org/10.3102/00346543067001088

Hofer, B. K., \& Pintrich, P. R. (Eds.). (2002). Personal epistemology: The psychology of beliefs about knowledge and knowing. Mahwah, NJ: Lawrence Erlbaum Associates, Inc.

Jehng, J. J., Johnson, S. D., \& Anderson, R. C. (1993). Schooling and students' epistemological beliefs about learning. Contemporary Educational Psychology, 18, 23-35. http://dx.doi.org/10.1006/ceps.1993.1004

Kardash, C. M., \& Scholes, R. J. (1996). Effects of pre-existing beliefs, epistemological beliefs, and need for cognition on interpretation of controversial issues. Journal of Educational Psychology, 88, 260-271. http://dx.doi.org/10.1037/0022-0663.88.2.260

Kegan, R. (1982). The evolving self: Problem and process in human development. Cambridge, MA: Harvard University Press.

King, P. M., \& Kitchener, K. S. (1994). Developing reflective Judgment: Understanding and preforming intellectual growth and critical thinking in adolescents and adults. San Francisco: Jossey-Bass.

King, P. M., \& Kitchener, K. S. (2002). The reflective judgment model: Twenty year oh research on epistemic cognition. In B. K. Hofer \& P. R. Pintrich (Eds.), Personal epistemology: The psychology of beliefs about knowledge and knowing (pp. 17-61). Mahwah: Lawrence Erlbaum.

King, P. M., \& Kitchener, K. S. (2004). Reflective judgment: Theory and research on the development of epistemic assumptions through adulthood. Educational Psychologist, 39(1), 5-18. http://dx.doi.org/10.1207/s15326985ep3901__2

Kitchener, K. S., \& King, P. M. (1981). Reflective judgment: Concepts of justification and their relationship to age and education. Journal of Applied Developmental Psychology, 2, 89-116. http://dx.doi.org/10.1016/0193-3973(81)90032-0

Kuhn, D. (1991). The skills of argument. New York: Cambridge University Press. http://dx.doi.org/10.1017/CBO9780511571350

Kuhn, D., Cheney, R., \& Weinstock, M. (2000). The development of epistemological understanding. Cognitive Development, 15, 309-328. http://dx.doi.org/10.1016/S0885-2014(00)00030-7

Lodewyk, K. R. (2007). Relations among epistemological beliefs, academic achievement, and task performance in secondary school students. Education Psychology, 27, 307-327. http://dx.doi.org/10.1080/01443410601104080

Marzooghi, R., Fouladchang, M., \& Shemshiri, (2008). Gender and grade level differences in epistemological beliefs of Iranian undergraduate students. Journal of Applied Sciences, 8(24), 4698-4701. http://dx.doi.org/10.3923/jas.2008.4698.4701

Mason, N., Boldrin, A., \& Zurlo, G. (2006). Epistemological understanding in different judgment domains: Relationship with gender, gender level and curriculum. International Journal Educational Research, 45, 
Nayebi Limoodehi, R. \& Tahriri, A.

43-56. http://dx.doi.org/10.1016/j.ijer.2006.08.003

Merriam, S. B., \& Caffarella, R. S. (2007). Learning in adulthood: Comprehensive guide ( $3^{\text {rd }}$ ed.). San Francisco: Jossey-Bass.

Muis, K. R. (2007). The role of epistemic beliefs in self-regulated learning. Educational Psychologist, 42(3), 173-190. http://dx.doi.org/10.1080/00461520701416306

Perry, W. G. (1970). Forms of intellectual and ethical development in the college years: A scheme. New York: Holt, Rinehart and Winston.

Phan, H. P. (2008). Multiple regression analysis of epistemological beliefs, learning approaches, and self-regulated learning. Electronic Journal of research in Educational Psychology, 6 (1), 157-184.

Pintrich, P. R. (2002). Future challenges and directions for theory and research on personal epistemology. In B. K. Hofer \& P. R. Pintrich (Eds.), Personal Epistemology: The psychology of beliefs about knowledge and knowing, (pp. 389-414). Maswah: Lawrence Erlbaum.

Ryan, M. P. (1984). Monitoring text comprehension: Individual differences in epistemological standards. Journal of Educational Psychology, 76(2), 248-258. http://dx.doi.org/10.1037/0022-0663.76.2.248

Schommer, M. (1990). Effects of beliefs about the nature of knowledge on comprehension. Journal of Educational Psychology, 82, 498-504. http://dx.doi.org/10.1037/0022-0663.82.3.498

Schommer, M. (1993). Epistemological development and academic performance among secondary students. Journal of Educational Psychology, 85, 406-411. http://dx.doi.org/10.1037/0022-0663.85.3.406

Schommer, M (1994). Synthesizing epistemological belief research: Tentative understandings and provocative confusions. Educational Psychology Review, 6, 293- 319. http://dx.doi.org/10.1007/BF02213418

Schommer, M (1998). The influence of age and education on epistemological beliefs. British Journal of Education Psychology, 68, 551-562. http://dx.doi.org/10.1111/j.2044-8279.1998.tb01311.x

Schommer-Aikins, M. (2004). Explaining the epistemological belief system: Introducing the embedded systemic model and coordinated research approach. Educational Psychologist, 39(1), 19-39. http://dx.doi.org/10.1207/s15326985ep3901_3

Schommer, M., Calvert, C., Gariglietti, G., \& Bajaj, A. (1997). The development of epistemological beliefs among secondary students: A longitudinal study. Journal of Educational Psychology, 89(1), 37-40. http://dx.doi.org/10.1037/0022-0663.89.1.37

Schommer, M., Crouse, A., \& Rhodes, N. (1992). Epistemological beliefs and mathematical text comprehension: Believing it's simple doesn't make it so. Journal of Educational Psychology, 84(4), 435-443. http://dx.doi.org/10.1037/0022-0663.84.4.435

Schommer, M., \& Dunnel, P. A. (1994). A comparison of epistemological beliefs between gifted and non-gifted high school students. Roeper Review, 16, 207- 210. http://dx.doi.org/10.1080/02783199409553575

Schommer-Aikins, M., Duell, O. K., \& Hutter, R. (2005). Epistemological beliefs, mathematical problem-solving beliefs, and academic performance of middle school students. The Elementary School Journal, 105(3), 289-304. http://dx.doi.org/10.1086/428745

Schommer, M., \& Walker, K. (1997). Epistemological beliefs and valuing school: Considerations for college admissions and retention. Research in Higher Education, 38, 173-186. http://dx.doi.org/10.1023/A:1024929619223

Sessa, V. I. (2006). Continuous learning in organizations; individual, group, and organizational perspectives. Mahwah, N.J.: Lawrence Erlbaum.

Winne, P.H., \& Hadwin, A. F. (1998). Studying as self-regulated engagement in learning. In D. Hacker, J. Dunlosky, \& A. Graesser (Eds.), Metacognition in educational theory and practice (pp. 277-304). Hillsdale, NJ: Lawrence Erlbaum.

Zimmerman, B. J. (2000). Self-efficacy: An essential motive to learn. Contemporary Educational Psychology, 25, 82-91. http://dx.doi.org/10.1006/ceps.1999.1016 